European Journal of Turkish Studies

Social Sciences on Contemporary Turkey

18 | 2014

(Hi)stories of Honor in Ottoman Societies

\title{
An Honorable Break from Besa: Reorienting Violence in the Late Ottoman Mediterranean
}

Isa Blumi

\section{(2) OpenEdition}

\section{Journals}

Electronic version

URL: http://journals.openedition.org/ejts/4857

DOI: $10.4000 /$ ejts. 4857

ISSN: $1773-0546$

Publisher

EJTS

Electronic reference

Isa Blumi, « An Honorable Break from Besa: Reorienting Violence in the Late Ottoman Mediterranean », European Journal of Turkish Studies [Online], 18 | 2014, Online since 10 July 2014, connection on 16 February 2020. URL : http://journals.openedition.org/ejts/4857 ; DOI : 10.4000/ejts.4857

This text was automatically generated on 16 February 2020

(c) Some rights reserved / Creative Commons license 


\title{
An Honorable Break from Besa: Reorienting Violence in the Late Ottoman Mediterranean
}

\author{
Isa Blumi
}

Besa e shqiptarit si purteka e arit (An Albanian's Honor is worth more than Gold)

\section{Introduction: The Problems of Telling a Violent Story}

1 Underlying any study wishing to account for fundamental changes in how societies function must be the quest to identify causes and effects of violence. Predictably, this has led to contradictory, if not ultimately confusing, narratives with as much left out of the story as imposed by the historian. What these contradictory stories ultimately suggest is that any attempt to study the animating factors leading to, and resulting from, violence in any specific moment will suffer from a fundamental flaw: The fact that a composite narrative misrepresents the reality of disparate and geographically scattered events. As such, any reference to bloodshed must account for the fact that any number of things can potentially contribute to different processes taking place at the same time (and even place), processes that cannot be neatly explained by reference to violence alone.

2 The following study invariably also suffers from this methodological weakness in that it too mobilizes a narrow selection of events/nonevents (at the expense of including others) in order to reinterpret the so-called origins and enduring legacies of violence in still understudied western Balkan areas during the 1800 to 1918 period. Among the underlying impediments to analyzing the disparate events identified as contributing to, for instance, the 1912-1913 Balkan Wars' long-term consequences rests, in part, on a narrow focus on specific administrative zones-the mountainous borderlands of Kosova, Işkodra, Serbia, and Montenegro known here as Malësi-and their inhabitants, without fully engaging seemingly peripheral events beyond these locales. However, as 
we learn from looking at events in such settings more closely, the long assumed sources of violence within the Ottoman Balkans-a resilient local culture of resistance-proved to have important, often forgotten, implications. These implications both transformed Ottoman state practices and the competing imperial ambitions in the region. ${ }^{1}$

Evidence of violent exchange in even "isolated" borderland regions like Malësi may require a careful reinterpretation of what documented violence actually reflects at several layers of social organization and institutional interaction. ${ }^{2}$ In the end, violent moments that appeared to mark the collapse of Ottoman rule in the western Balkans, often seen in regional historiographies as an ascendency of local practices that in turn reflect primordial ethno-national associations or practices, need deeper inspection, not sweeping retrospective assertions. ${ }^{3}$ One perfect example of our need to excise carefully any undue anachronisms from our interpretations of violent events in the Balkans is how we treat events in the context of the establishment of an Albanian state in the post-Ottoman era.

4 To many scholars wishing to glean significance from enduring tropes about a Northern Albanian culture of violence-predicated on the honor-bound enforcement of local laws whose very documentation justifies scholarly presumptions of significance in the matters of day-to-day existence of peoples living in Malësi-the very existence of "tradition" constitutes validation for assuming linkage (Burda 2012). Earlier generations of social scientists had an equally utilitarian notion of culture and folklore, one that both neatly confined the object of study to a unit of analysis and enabled the observer to anticipate ways to influence these disparate constituencies in the affairs of state. For example, to agents of external powers-especially the Habsburgs and Britain -flirting with indigenous practices seemingly helped them offer insight into how to best manipulate the affairs of Northern Albanians. ${ }^{4}$

5 While local practices based on Albanian "honor codes" or besa may have played a role in helping forge an insurgency that at one point contributed to the destabilization of Ottoman rule in the region, I wish to suggest such cultural affinities cannot substitute for an explanation of why locals resorted to (or threatened) violence. Here, I offer at once a set of possible alternative ways to understanding the motivation behind certain policies vis-à-vis the region's inhabitants and also a complication to what it is we assume is Albanian honor, a complication that aims to correct an indigenous sourced essentialism so many scholars mobilize to explain events in the western Balkans (Pula 2013). As such, this study looks into tensions around the regulation of honor codes in Albanian territories in order to undermine the authority of discourses of the "native", both iterated from those speaking on behalf of said "native" and the operatives of state seeking to harness them.

6 Crucially, both sets of narratives are as much the manifestation of a product of policy and/or indigenous agency that seeks to harness local violence as they are a neat sociological variant useful for explaining community. ${ }^{5}$ In this respect, I am suggesting that observed tension in the archives frequently mentioned in historians' depictions of events in the Ottoman Balkans may be but extensions of intricate domestic disputes that are themselves marked by gradations of possible violence as much as actual violence. ${ }^{6}$ By nuancing this reading of violence through a skeptical reevaluation of the utility of honor codes synonymous to those of the "highland peoples" of Northern Albania in the late Ottoman era (called Malësorë), I am hoping to initiate a new approach to monitoring social dynamics in the Ottoman Balkans. As such, this is not 
only an exploration of honor politics in an Ottoman context, but also an exercise in revisiting neglected cases of indigenous sources of change initiated by Albanian officers of state that are otherwise obscured in the literature by the violence of the First World War.

\section{Methodological Issues: The Ottoman-Albanian Effendiyya Agent of State}

7 There is an interesting tension in the way men linked to the generation of native-born state reformers orientated themselves toward their homelands in the Ottoman Balkans. Because of the disproportionate number of natives of the western Balkans region making up the cadre of Young Ottomans, many expected to help administer their often volatile homelands faced the awkward task of claiming authority on the basis of their direct association to a society that many Ottoman elites believed was in desperate need of state rule. As a result, many native Albanians became the main ideologues to justify the extension of state power into areas largely autonomous from Istanbul in the past, but they would do so evoking the very "racist" tropes that are assumed reserved for non-natives. Undoubtedly, these "self-hating" Albanians, Bulgarians, Greeks, and Vlachs would prove to be the most virulent advocates for the kind of "harsh love" in the Ottoman Balkans long associated with a particularistic European colonialism (Makdisi 2002).

The problem with studying Ottoman state expansion-as-reform is that there is always the danger of thinking of the effendiyya "class" implementing such policies as a monolith. To the contrary, there were internal divisions, factions, and ultimately rivalries that reflected the initial geographic, social class, and "ethnic" diversity of this bureaucracy. This diversity impacted how reforms were actually implemented. In fact, there is evidence that these reforms often treated as part of a generic "Tanzimat" or "modernization" era were not applied uniformly in the Balkans at all. Often the more lucrative projects and its big budgets went to the home districts of officials while the more authoritarian measures were dedicated to underrepresented areas deemed "savage" or "backward" in the documents. ${ }^{7}$ In this respect, reports promoting either neglect (what is the point of throwing money down the drain) or heavy investment (these subjects need greater state presence), reflect a local flavor that is sometimes lost to historians eager to explain Ottoman era reforms (İnalc1k 1993).

9 In crucial ways, native-born bureaucrats, often hailing from southern Albanian regions known as Toskëri, administered each region, in each distinct instant, with different variations of reforms-as-state-building-tools. This suggests a manner of applying state power that was always mitigated by a combination of local conditions and personal connections to the communities slotted for reform. There was, in other words, a local and personal context to the way "modern reform" and its violence (or potential) was implemented as well as experienced.

10 As suggested throughout, one cannot help but read a quasi "colonialist" attitude in the correspondences of native-born bureaucrats discussing the affairs of their tumultuous homelands in the western Balkans while expanding Ottoman state authority there. In almost absolute ubiquity, when analyzing the conditions in the western Balkans, these 
native-born reformers put emphasis on the special role of the state in changing the region from being entrenched in old customs to becoming part of the modern world.

11 Revealingly, these policy agendas were regularly iterated in almost racist tones, where "reform" in the provinces entailed "civilizing" local populations. While such attitudes have been already observed in the Ottoman story, it is in this case actually the "nativeson" who used the racist colonial epistemology to justify "governing" his homeland as a hostile land in need of "civilizing" violence. As is often the case, the scholarship that conflated the violence of "savage" peoples disguises an ambivalent admiration, one generated by fear and seduction for the exotic. ${ }^{8}$ As such, the negative contrast so often evoked in scholarship on such "othering" is often reversed: in being based on a sense of personal and collective dignity, and by conferring the power of execution on the family or community rather than on a formalized punitive state apparatus, highland Albanian custom seems finally more capable than modern laws of guaranteeing justice and thus bringing order to regions seemingly out of control. In other words, native-born members of the Ottoman state apparatus were the greatest apologists for Ottoman bureaucratic expansionism in the western Balkans during the nineteenth century (Avlonyalı Ekrem Bey 2006).

While conflicts of interest may translate into a positive flow of government funds and jobs for many in the western Balkans, it could mean an imbalanced, unjustified use of negative government power for others. This incongruence is possible to identify, however, only if we disaggregate the bureaucracy, breaking apart the generic into more detailed units of observation. This requires distinguishing the native-born from the nonnative as well as going a step further and understanding that being from one village, kabile, or fis (Albanian for clan) and not the one from which a reformer came probably determined the quality of "reform" in one area or another.

In many ways, the literature is trapped by the formal categories used to understand events prior to World War I. Scholars of many disciplines, especially those trained in national academies in the region, learn to draw explanations for events from a lexicon largely constructed as part of post-WWI narrative. These vocabularies reflect strategies that seek to privilege the undifferentiated "nation-state" and its essentialist "ethnonational" character over the many different possible socio-political, economic, and inter-cultural orientations still at play in each "country" (Boškovic 2005). What ends up untold are the complex intermediate factors that often undermine the explanatory value of references to, for our purposes here, highland Albanian traditions of honor (Galaty 2013).

In the period of 1800 to 1918 , local and regional politics of the western Balkans were messy, with competing factions operating under very different conditions depending on their relative position vis-à-vis imperial state competitions, sources of revenue such as mines or forests, or disputed borderlands. These factions, often changing in composition over even very short periods of time, catered to very different constituencies, be they in Austrian-administered Bosnia and Sanjak (Sancak in Modern Turkish), rural Macedonia, or the various coastal trading towns of the Adriatic and its hinterland. Rather than trying to clarify these complications, I wish to add to them by considering some of the conflicting agendas among those fluid clusters of actors straddling the political and commercial frontiers of the western Balkan provinces of the Ottoman Empire. In fact, it will be the intersections of multiple interests that prove especially useful to reconsidering what role implicit local violence (as opposed to actual 
violence) played in informing state and group actions. Identifying the threat of local Albanian violence, one that has always threatened the already fragile imperial order established by way of complicated interactions between local claimants to authority and external state authorities, may initiate new approaches to classifying "subaltern" agency that avoids reifying essentialist (Orientalist) tropes of the marginal in modern imperial states. That the lie of indigenous "honor" (besa) codes uniquely informed Albanian behavior was not only an extension of objectifying the "uncivilized" for purposes of "colonial knowledge", but also of a set of possible rhetorical/ideological claims made by (and sometimes about) Albanians, forces us to take a new look at just where historic agency sits.

As discussed below, it is the ever-present possibility of violence that shapes how government officials, individuals and their communities in Malësi (called Malësorë) adapt to contingencies for which they themselves ultimately are responsible. Crucially, just how such officials and the objects of official reports-in our case here, Northern Albanians-cater to the reductive and misrepresentative tropes of the mountainous regions of the Balkans thus potentially becomes part of a dynamic that shapes a discourse of governance both in Istanbul and locally. In other words, the occasional reference to besa in Ottoman documentation and among indigenous actors may reflect a strategic attempt at harnessing Albanian honor in order to assure stability by way of threatening (or warning of) violence if certain measures are not taken. As such, policies were developed around as much the concern about the possibility of violence as actual violence itself, a concern that may have dominated the modern state's rise in the early twentieth century to such an extent that indigenous "agency" may prove the critical intermediary force behind much of what we today assert is "modernity" (Blumi 2012: 94-116).

Due to the way physical, organized, and specifically directed violence transformed the texture of life in the Balkans immediately during and after the Tanzimat era, individuals and the communities they made often invested in new forms of association. These associations invariably conflicted directly with some evolving state-building projects as appeared in modified form after the Balkan Wars of 1912. In the case of the western Balkans, the very process of occupying Ottoman lands after victory in 1912, often by regimes composed of political and commercial elite with strong residual associations with the Ottoman state, suggests an intimacy between "enemies" that is neglected in the scholarship. There are, in other words, considerations at play that cannot rely on the clichés that leave an ethno-national or essentialist sociological imprint on the way we write about violence in the Ottoman provinces.

17 Taking this interpretive range into consideration, this study identifies different kinds of short and long-term social and political consequences of violence, as a conceptual possibility as much as an experience. In the first part of this intervention, I wish to highlight how ambiguous and inarticulate forces afflicting the larger post-empire regimes since 1912 misleadingly suggest important causal factors to the collapse of internal relations crucial to maintaining regional stability. Contrary to common belief, however, much of the problems associated with the increasingly manifested violence in the region actually stem from the idiosyncratic applications of "policies" (and how historians have chosen to read them later) that seemingly undermined the capacity of various state administrations to manage their regional affairs effectively in ways other than by way of violence. These "policies" correspond with a crucial outburst that 
animates much of the post-Ottoman Balkans/Anatolia/Middle East in the form of the "nationalist revolt" retrospectively imposed by the scholarship.

The problem with writing this study on honor codes in Ottoman Albania is these forms of interaction so communicable to a twentieth-century audience cannot so easily be assumed to mirror what are essentially post-Ottoman social and political orientations that still require a World War to take place. In other words, the implicit threat of violently disrupting social order in post-Ottoman societies by way of mobilization along "ethnic" lines (often couched in terms of a community's "honor") proved only valuable in certain contexts; other forms of threats of violence (with actual displays of violence recorded at times) also animated daily politics. Linked to these periodic bursts of violent opportunism by indigenous actors tied to external as well as domestic interests (again, this did not have to mean literally violence, but its evocation as a form of threat) is the failure of Ottoman state mechanisms to resolve residual conflicts within, for our purposes here, "mixed" communities. The apparent failure to adapt approaches to resolving potentially (or not always) violent conflicts along the borderlands of the former Ottoman provinces led to the series of contingencies that animated new kinds of political forces.

It is crucial to highlight here that this is not to deny that authorities evoked Northern Albanian propensity for violence. Frequently in reports, the stereotype about Albanian stubbornness, bravery, backwardness, and hot-bloodedness seemed to determine policy decisions. There was certainly some kind of bureaucratic "understanding" of what were the essential forces at work in these dangerously volatile regions. My question here is just who was promoting these themes in the larger cultural context? Answering this in more complicated ways may provoke new suspicions about just what is at work in the Balkans during and after the Ottoman period.

To the many natives of the western Balkans who formed a large part of this bureaucratic class, the larger spirit of reform meant harnessing their localism to a larger state apparatus. With this considerable potential for power, they then often projected back to the region their personal and collective prejudices, which translated into exploitative, arrogant, and even violently hostile policies toward select groups. For many Young Ottomans of southern Albanian (Tosk) origin, therefore, the opportunity to "reform" parts of the western Balkans meant "naming" and characterizing the "nature" of these regions as well as devising schemes to implement "development" or "expansion" that again would seem to mirror the patronizing, often racist discourses associated with western European colonialism of the same period. This may constitute the long-term project of transforming the Wild Man of Albania's highlands into a Noble Savage whose historic role would eventually be mediated by retrospective appropriations of heroic, nationalist violence. Such a marked transformation of roles for the Ottoman Albanian highlander poses, however, crucial ethical as well as methodological problems for us trying to historicize such policies today.

21 Hayden White (1972) has traced the place of the Noble Savage in western culture: Sometime in the late seventeenth century, says White, the image of wildness is fictionalized, that is, separated from an imagined essence of wildness that is turned to limited use as an instrument of intra-cultural criticism. Deriving from natural virtues long associated with the backwardness of uncivilized peoples, the Noble Savage serves as a positive contrast to the coercive norms of European civilization that unleashes such violent power. The indigenous guardian of local tradition thus can offer a 
resistance that in the right moment, reflects not only wildness, but functions equally as a valorization of those values lost to Modernity.

Rousseau contributed to this discussion. Not only is the resistance of the savage an indictment of imperial violence with the "natural state" of the non-European fundamentally "free" and thus superior to the civilization from which Rousseau's readers come, but the savage also provides the historical tension that makes/breaks empires. Another admirer of the outsider, Lord Byron, penned tropes to flesh out poetically what others sought to identify when challenging the Enlightenment and its inherent violence. The descriptions of Albania in Canto Two of Childe Harold's Pilgrimage anticipate the descriptions of Anatolian landscapes found in literature, letters, and reports filed by numerous idealistic Europeans, in particular missionaries. Albania, the domain of the savage men that offered a sublime alpine topography with a culture that is an amalgam of the Islamic faith and traditions of the warrior tribe is captured by Baron thus:

Fierce are Albania's children, yet they lack / Not virtues, were those virtues more nature / Where is the foe that ever saw their back? / Who can so well the toil of War endure? / Their native fastnesses not more secure / Than they in doubtful time of troublous need: / Their wrath how deadly! but their friendship sure, / when Gratitude or valour bids them bleed - / Unshaken rushing on wherever their Chief may lead (Lord Byron 1812).

Here then are all the topoi to be harvested by various "Orientalists" working for empire, right down to specific ethnographic details: the savage lived a violent but dignified existence, one rooted in a chivalrous code of behavior.

The Noble Savage is perhaps the most significant allegorical figure in the mythology of the western Balkans. If the Wild Man remained a shadowy nocturnal menace, the Noble Savage allowed for the emergence of the North Albanian highlander as a central protagonist in the shaping of modern, post-Ottoman, polities. Importantly, these criteria of prejudice were never fixed, and they were constantly changed as the world transformed around them. Individuals and groups alike constantly translated the meaning and value of these systems of differentiation-linking one's association to regional affiliations Geg/Tosk, Bektashi/Catholic-to perceptions of power that, over the course of the nineteenth and early twentieth centuries, changed in often dramatic ways.

The task now is to begin understanding these relations at their most subtle levels to retell western Balkan histories vis-à-vis the overhanging presence of violence (or the possibility of violence) during the late Ottoman period.

Studying what are ultimately exchanges rather than clashes reveals how Ottoman intellectuals and the western Balkan "masses" were equally complicit in a process that transformed the imperial project. In many ways, their attempts to assert distinctive associations in the terminology of millet and the disaggregation of those within each assumed "national" group gained importance in the late nineteenth century as many members of the Ottoman Balkan elite articulated frustrations with the lack of social mobility and perhaps the feeling of being trapped on the periphery of a more cosmopolitan and dynamic Ottoman society. It is at this time when various "identity" claims were reflected both in categories of state and local practice and as a category of analysis. As a category of practice, it was used increasingly (but not always!) by actors in everyday settings to make sense of themselves and their activities and, thus, 
communicate their specific interests to others through relative violence. Often, the identity claims used were framed in geographic terms with immediate assumed social proclivities towards violence induced by powerful "honor codes" long associated with "tribal" peoples throughout the region. So at one point, a set of local interests could be presented in the form of the immediate community-Hoti, Gruda, Kelmendi, and Kastrati-larger confederations of communities-Malësorë, Gegë, Bijelopavlić-or finally, entire regions-Montenegro/Karadağ, Kosova, Macedonia, Albania/Arnavutluk.

It is this last spatial configuration that is especially interesting; the evocation of what were geographic abstractions to identify a larger possible constituency, for instance, "Prizren", "Drenica", "Montenegro", or "Arnavutluk", was increasingly used to persuade some locals to understand themselves momentarily in one productive way and not another. The fact that such efforts were at the same time informed by concerns with lingering, parallel loyalties, shaped by regional stereotypes that created a conflicted interface between would-be nationalists, Ottoman loyalist instilling Ottoman nationalism, and "locals".

The peoples known as Malësorë, Gegë, Bijelopavlić were all to be directly associated with a particularly popular cultural explanation for the occasional violence in their home regions. Being synonymous with violence required, however, further nuance that especially catered to the Albanian bureaucratic elites' claims to having a particularly unique set of skills to "understand" these agents of potential violence. As such, a growing field among the reformist classes was to promote the ethnography of highlander "honor codes" to both suggest a primordial set of practices that, with proper oversight, could be harnessed, as well as suggest an explanation for why violence in strategically sensitive areas like these borderlands needed the direct attention of well-placed Tosk Albanians.

What is crucial to draw from exploring this interesting side effect of Young Ottoman policies is that these were all contingent and short-lived. The reification of different identity associations proved to be a social process, not just an intellectual practice. Analyzing this kind of politics leads us to an accounting of processes and mechanisms through which what has been called the "political fiction" of the nation becomes but one of many possibilities available to the many competing stakeholders in the western Balkans. As I constantly wish to iterate in my larger body of work, we must be careful not to assume that these periodic claims to broader associations mean what most postOttoman historians claim them to mean. These suddenly "modern" expressions of longused strategies of engagement by locals vis-à-vis the larger world betray the underlying tensions of the empire often forgotten in the literature on Balkan nationalism.

Drawing on recent studies of late Ottoman literature and social commentary, in particular, helps to highlight how Ottoman intellectuals did not interpret events as manifestations of European, and thus foreign, cultural hegemony. From Ali Cevad, Lütfiye Hanım, and Ahmed Vefik to Ahmed Cevdet, Ottoman observers believed that local factors, along with outside machinations, accounted for the temporary, parochial, and isolated events in the Balkans (Boyar 2007). More importantly, these witnesses were particularly certain that the animating factors behind the occasional outbreak of violence were not linked to what we today call nationalism, but a primitivism that needed modernist intervention.

31 Crucially, the contingent actions of locals actually frustrated the ambitions of outside states as much as those of the Ottomans themselves to more clearly unify these 
communities. This proves crucial when considering the impact that contingencies had on how prominent Ottoman Balkan natives responded to the forces pushing and pulling the empire during the course of the middle years of the nineteenth century.

The demonstrably ideological constructions of the "people", therefore, did not take place in a social, cultural, or political vacuum. The targets of what became nationalist romanticism actually determined the extent to which important early "nationalists" could recreate their idealistic vision of the nation while also remaining committed to their Ottoman universe. We see this with the examples of the creative work of Sami Frashëri/şemseddin Sami (henceforth Sami) (Kaleşi 1973).

Prominent southern Albanians such as Sami Frashëri formed a cohort that, even when faced with challenges to the empire, for the most part did not take the separatist route. Writing poems and plays, these men would serve as the foundation of the next phase of adaptation starting from 1875, when the world in which they emerged again threatened to crumble. That being said, they did not constitute a monolith easily framed in post-Ottoman categories like "Albanian". They operated within a set of fluid social roles and thus had often contradictory expectations. The divergent careers of many can be appreciated, therefore, only by considering their individual ambitions, the impact reform efforts of the Ottoman state had on their particular set of networks, and the growing presence of outside powers whose money and promises of new kinds of opportunities successfully disrupted temporary alliances.

In this period, Ottoman state agencies presumed considerable power over the same "uncivilized" locals. At times, the overwhelming shift in strategies seemed to follow a clear trajectory toward a monopoly of coercive power in the hands of the state. Local despots linked to various ministries and parliamentarian bodies alike entertained absolutist ambitions as outsiders invested resources into a new vehicle-the state-to maximize the capacity of private capital to extract surplus from the world. Scholars in the twentieth century often unquestionably treat these confrontations in the Ottoman Balkans as representations of an indigenous effort of separation on the basis of a language, religion, sect, or historically fixed geographic terms. This is especially clear in regard to the misrepresentation of the drive to create a single mega province such as Syria in the Middle East, Tuna (Danube), Prizren, and then Arnavutluk (Albania) by key members of the Young Ottoman generation. What is conveniently forgotten is the context in which reformers such as Pomok Midhat Pasha initiated the last phase of reforms that created these mega provinces (Petrov 2006).

Some of the schemes that Midhat Pasha developed were the insertion of direct power via a newly reformed police force, the expansion of infrastructure, and schooling in the Niš sancak he governed. These policies coincided with the larger civilization-building project found throughout Europe at the time and mirrored the sentiments already discussed above among other native Balkan members of the Ottoman government. In other words, Midhat Pasha and the elite he represented began to convince historically independent communities to see their immediate interests as extending beyond the confines of their traditional areas (Saraçoğlu 2008).

The 1850s in autonomous Ottoman principalities such as Serbia and Montenegro witnessed a number of important measures implemented in the attempt to consolidate power around landed elites, a set of power shifts that translated into new forms of identity politics paralleling those in the rest of Europe. In rapid succession, the Ottoman state responded to some Slav leaders' increasing overtures to Russia by 
investing considerable resources into securing, for instance, the area around Shkodër, the commercial hub of the region bordering Montenegro. Of the government agents charged with securing the area, the first, Ömar Lüfti, proved controversial (and counterproductive) because, between the years 1851 and 1853, he initiated the first attempt at directly taxing local communities (Reinkowski 2003: 249).

As a result of the predictably violent resistance to these taxes, a new generation of state officials elected to adopt a different set of reforms that spent less time focusing on taxing local landowners and more on simply co-opting them to serve the government in some capacity. For instance, under a new governor, Mustafa Pasha, the Ottoman state invited prominent locals to join a committee that brought all communities of Malësi together. ${ }^{9}$ Community leaders in the immediate area around the city of Shkodër who joined this committee, called the Committee of the Shkodër Mountains (CSHM), were given formal titles and salaries and were charged with the responsibility of ensuring stability and the smooth administration of areas previously only nominally under state control. Such overtures initiated a process of regional integration that would open the door for greater direct state rule in these previously isolated regions. They were also forged on the assumption certain hierarchies existed and entire regions could be best administered by co-opting members at the top of these pyramids forged by honor (or besa) pledges (Rira 2012).

The Young Ottomans, in other words, were institutionally formalizing a communal identity of the Malësorë for the purposes of administering the region under a regime that avoided the outbreak of possible violence. Of course, to do this effectively, they sometimes needed to manipulatively exaggerate the threat of violence to those holding the purse-strings, knowing full well that the stereotypes about the violent nature of the highland Albanians would be persuasive justification for the delivery of even more state resources. In this respect, while their agenda may have been to consolidate the authority of the Ottoman state, the principal agents of this policy at the local levelHasan Tahsini (first director of Istanbul University, known in Albanian literature as Hoxha Tahsini), the Frashëri brothers, Zef Jubani, and Pashko Vasa ${ }^{10}$ - were not immune to the regionalism that the reforms had sought to erase. For one, considerable tension existed between these activists of reform and the constituents they hoped to co-opt in large part because these state representatives, even though they were "Albanians" in some sense, were largely viewing their local intermediaries through the prism of their proclivity for primitive cultural habits. This tension distorted an otherwise straightforward example of state centralization that confounds the simplistic nationalist paradigms in vogue today.

\section{Reforming Home for the Empire}

Since Tosk officials played a central role in the application, if not the outright design, of these policies in the western Balkans, the seat of government in Istanbul adopted different strategies for Tosk and Geg territories. As already suggested, Toskë based in Istanbul and embedded in the reformist regime had few to no links in Kosova and Işkodra while maintaining strong personal connections with their home regions further south. As a result, Tosk Ottoman reformers were selective when evoking the expansion of direct state control of the western Balkans. One of the ways this was manifested was the attitude of Tosk elite toward the mountainous regions in Malësi, 
which they believed constituted the biggest threat to Ottoman development. The projects adopted by the future luminaries of Ottoman-Tosk culture were thus underpinned by a clear sense of frustration over the lack of "order" in the mountainous regions. Among other things, these reformers felt that unless these autonomous mountainous regions were formally incorporated into the larger Ottoman society, it would be through these areas that Russia or Austria-Hungary would be able to penetrate the empire. Events further to the north in Bosnia during the 1860 s and $1870 \mathrm{~s}$ proved these fears to be justified. The idea then was to promote an aggressive campaign of civilization building at the expense of local autonomy, and often at the end of a gun. ${ }^{11}$

Already in 1857, reformers were attempting to expand on earlier efforts to assert state influence in Malësi by working with the local Catholic clergy, who were asked to address the so-called blood feuds problem, a debilitating series of vendettas that had kept highland communities in a state of perpetual warfare. In lieu of using force, new strategies to bring the region some stability included the strengthening of a religious presence (by building more churches and mosques) and a greater investment in direct government involvement in the area by building police stations, courthouses, and schools. As revealed in the fine work of Hasan Kaleshi (1964: 110), Ottoman reformers started to address these issues by slowly establishing judicial uniformity and normalizing the daily interactions between state officials and the local population. In particular, reformers hoped that the investment in government structures could solidify the authority of Ottoman judges, who, with the coaxing of clergy, would begin to replace a violent social domain largely inaccessible to the state. In essence, the goal of these early reforms was to replace the local leaders who had been the major arbiters in peoples' lives with streamlined state surrogates who would always assist Istanbul while helping unify a society traditionally fragmented by blood feuds.

41 At times such efforts would require the old strategy of simply co-opting rivals by appointing them as the chief of a newly created police station or the headmaster of a new school. The subtleties of modern state-building, however, did not allow for this age-old policy of buying loyalty and pitting rivals against each other to be the sole substitute for direct rule. New methods initiated during the Tanzimat took a cultural track as much as an institutional one. In the context of instituting greater direct Ottoman administration of the highland regions, an often public animosity toward the "tribal habits" practiced in "savage mountain districts" increasingly made its way into the documents and early newspapers (Deringil 2003: 322). The strong community identifiers along fis or "tribal" lines in the highlands clearly juxtaposed loyalty to family and community with good citizenship, as demanded by the Tosk officials linked to the Ottoman state (Reinkowski 2005a and b). The assumed inaccessibility of such communities required direct state intervention that combined bureaucratic measures and cultural chauvinism.

In the end, the rise of tropes about backward tribal culture represents a crucial shift in the Ottoman rule of the western Balkans. For many Ottoman officials from Tosk regions, the Malësor savage was as much a tool of state expansion as the institutions that were meant to civilize these people. ${ }^{12}$ Such thinking has parallels in other modern societies of course and scholars theorize such relations in the literature. Much like the Ottomans, other empires faced similar administrative problems as they absorbed large tracts of the Americas, most of Africa, and southern Asia. 

not arise from the Tosk Ottoman elite alone. By the time the Tanzimat reformers were making their move into the region, native sons were also vocal critics of the Malësore resistance. The few agents of state expansion who actually came from the regions targeted for reform were prepared to accommodate not only the growing state presence in their homeland but also its use of some of the more pernicious cultural tools of the modern state: the politics of civilization. For example, both Zef Jubani and Pashko Vasa, influential Gegë with long track records of service to the Ottoman state, shared with their Tosk allies a certain intellectual distance from the people living in the north, particularly the rugged mountains. In particular, Shkodër-native Zef Jubani decried the failure of the Tanzimat reforms to reach the Malësorë. He not only blamed bureaucratic incompetence for this but also offered a cultural explanation for the ultimate failure of reforms to reach the region: Jubani saw the continued lack of government presence in these areas as the result of the resistance by the "uncivilized" Malësorë to progress by way of intractable "honor" codes.

As I discussed earlier, this strategy, at least in the western Balkans, originated when a number of Ottoman reformers, including many Toskë and several Gegë, wanted to smooth over the communal signifiers of difference-religious or "tribal"-increasingly stimulated by outside patronage. To accomplish this, reformers until the 1860 s advocated a realignment of the institutions governing the provinces in the hope that they would help create, through educational and economic development schemes, new criteria of association advocated by the work of Sami Frashëri.

\section{Sami: The Patriarch of Tosk Cultural and Regional Elitism}

From his earliest writings in the 1870s until his death in 1904, Sami probably represents the single most important Ottoman intellectual of the Hamidian period. ${ }^{13}$ Contrary to the way he is portrayed today, a close look at his work leaves the impression that he wavered throughout his adult life with conflicted loyalties. Both Turkish and Albanian historians have made persuasive arguments linking his work to larger exclusivist narratives; their strategies have focused mainly on either ignoring the consequences of studying Sami's entire body of work outside its Ottoman context or, at best, vetting his writings that contravene their particular frame of analysis as mere intellectual anomalies.

It would be a mistake, however, to see Sami Frashëri's "contradictory" loyalties as in any way strange in light of what happened throughout the western Balkans during this period. Seeing oneself as sharing a regional heritage with a larger Ottoman identity was not necessarily a contradiction in the late Ottoman period. ${ }^{14}$ Instead, Sami's vast body of work on the Ottoman language and the composition of his invaluable encyclopedias all speak of a man firmly embedded in an intellectual current connecting him to likeminded Ottomans and the larger world (Dağlığlu 1934). As a result, his purported links with the parochialisms of Albanian nationalism is more a reflection of post-Ottoman cultural politics than a meaningful observation of the context within which he and his political allies were operating at the time. 

writings all point to an attempt to strengthen the Ottoman Empire by lecturing and, if possible, shaming Gegë and especially Malësorë for the manner in which they engaged with the world around them. Sami's first serious work, the play discussed below, and his many articles published in Istanbul newspapers all focused on a social engineering theme that reflected the general spirit of his generation: reforming the cultural peripheries of Ottoman society. Moreover, much like the reformers based in the Balkans, the idea of a single regional province (be it Arnavutluk or Prizren) became central in his mind to protecting what remained of the empire's Balkan territories and preserving its Islamic heritage. ${ }^{15}$ it would be the task of educated, "civilized" men such as Sami and his brothers to edify the backward regions of the Ottoman Empire on this point. In one of the most celebrated works attributed to Sami he actually discusses at length the differences between Gegë and Toskë in terms of the savagery that paradoxically helped to preserve archaic forms of authentic Geg culture while the Toskë were changed by western civilization. Admittedly, his informative ethnographic studies also emphasized these regional differences..$^{16}$ According to Sami, the principal distinction between people alongside their geographic distance was their level of education. Couched in terms of being civilized and uncivilized, Sami clearly delineated the role that subjects of the Ottoman state would play in the reform efforts that energized his generation. Often one finds in his work direct reference to the intellectual and cultural gap that existed between "tribal" highlanders and his own educated cohort. In this context, Sami used the trope of the quintessential "warrior race" and their cultural tools, revolving around the "besa" (or oath sworn "in blood", with which much of the Ottoman public was familiar), to discuss the state's role in shaping Balkan life. ${ }^{17}$ In this regard, some of Sami's work introduces a counterintuitive dynamic in which he hoped that Malësorë and highland peoples throughout the Balkans would feel obligated to join in the effort of strengthening and unifying the empire's vulnerable northern frontier.

First released in 1874, Frashëri's play Besa Yahud Ahde Vefa (Besa or testimony of loyalty) represents quite vividly this underlying tension in Ottoman elite circles.$^{18}$ Particularly among the Toskë who made up a significant proportion of the empire's educated elite, the uncultured, brutal, and fearsome highlander was a problem. Sami's play reveals this sentiment inasmuch as it tries to lay down for his audience a stark contrast between the habits and customs of uneducated mountain peasants and people who were cultured, urbane, and part of a structured hierarchy. His characters spell out the dividing line separating civilization from barbarity and imperial demise from the promise of the empire. The tragic lesson of his story is the danger of deviating from a clearly laid out Tanzimat plan that suppresses the application of personal and communal law to ensure the exclusive arbitrator role of the state. ${ }^{19}$

For Sami Frashëri and his fellow intellectuals based in Istanbul, the practices of blood honor and strong "clan loyalties" were particularly detrimental to the efforts of the Ottoman state to bring reform to the key frontier districts. ${ }^{20}$ This is evident in Sami's play as he blurs the lines normally separating the hero from the villain. One of his main characters, the southern-born Tepedelenli Demir Bey (by designation, a gentleman and officer of the state), is used to issue a warning to the audience. One of his own officers, who himself is from a respected city family, threatens the natural hierarchy in the 
Ottoman society by lusting after a beautiful village girl who is already engaged. Demir Bey warns the audience that the educated, urban, and noble families charged with administering the wild lands should refrain from interfering with the domestic affairs of the "tribal" characters found in the mountains. In other words, one needs to stick to one's social and political circles when it comes to issues of family and romance. As the audience is forewarned, tragedy befalls the region when an impetuous junior ignores Demir Bey's pleas to not mix with the highlanders and pursues the innocent local beauty, whose own loyalties and love (both pure and idealized) rest with a man of her community. In the end, it is clear to the audience that trouble comes to those who disrupt a pattern of socialization that, while perhaps archaic, still needs to be respected (şemseddin Sami 1875: 89-100).

51 Juxtaposed with this message of class boundaries is the confrontation between power and injustice that makes Sami's play a helpful tool for studying the entire period. The Tanzimat was not meant to bring state power to bear on the wild people of the mountains as much as justice, order, and the straightforward application of the law throughout the empire. While the violence of local justice clearly denotes the necessity for universal legal codes administered by the Ottoman state, it is not just the backward customary law that needs regulation. Demir Bey, the appointed official and powerful landlord of the region, is also culpable in Sami's play. He oversteps his authority when he tries to compel a father to surrender his beautiful daughter to the governor's infatuated officer. While Demir Bey is wise enough to advise his officer not to pursue a shepherd's daughter, he still makes the fatal mistake of acting unjustly toward the father when his officer's impetuous behavior leads the locals to challenge the hierarchy of power. While they should not interact with locals, the moment the latter resist the wishes of the elite, all codes of behavior must take a back seat.

Interestingly, Sami uses the illiterate, simple but proud shepherd to alert the audience to the fact that after the Tanzimat reforms there can be no more arbitrary use of power (ibid.: 102-105). This is the second side of Frashëri's story: the Tanzimat is the mechanism that preserves order, and while respect is due to the class of powerful men, they cannot abuse it by simply imposing demands, especially unreasonable ones such as handing over an engaged daughter to a smitten officer. The consequences for the empire are dire.

Through the mechanism of a stereotypical representation of the form of agreement in highlander societies predicated on honor-the besa-Frashëri offers in his play a social formula for integrating Malësi, Gegëni, and the southern highland communities into the Ottoman fold. No longer shall true subjects be loyal to backward ideals and customary laws. Rather, through their "ancient" honor-bound system, they shall declare an oath/ besa to the empire as a mechanism that will free them from their self-destructive behavior, while also promising them just treatment by enlightened and restrained governors. United under the guidance of the Ottoman state, these simple people could serve a vital role in preserving the homeland (vatan): in this context, a vital part of the Ottoman Empire.

The rise of the autocratic Hamidian regime and consolidation of the palace's authority at the expense of a generation of liberal state reformists led to 40 years of give and take in the halls of power and provincial governance. As argued elsewhere, in response to the 1877-8 fiasco, members of the Midhat Pasha generation did not give up, but actively continued to lobby the Porte and then secretly created underground 
movements to advocate the reinstatement of a policy that reconstituted the western Balkans into a single administrative area dominated by a Tosk Arnavut ruling class. ${ }^{21}$

The apparent ascendancy of Pan-Slavism in the Balkans as a result of Russia's military victory rendered obsolete these early attempts to secure loosely defined constituencies by way of reordering provinces to fit within one administration. The strategy of creating the mega province of Arnavutluk, in particular, would ultimately be sacrificed as a new political order in Istanbul followed the palace coup of 1876 and the rise of the new sultan. This new state of reactionaries responded to the nearly total military defeat that was instigated by divisive forces of communalism originating outside the empire-Pan-Slavism and the Megali Idea-with a new strategy for social organization. Abdülhamid's regime would not equivocate and constantly experimented with tactics to disrupt the ability of groups to consolidate influence over vulnerable populations, a strategy Tanzimat reformers had once believed would help Istanbul rule the empire more efficiently. What happened in 1877-8 thus exposes a significant strategic divide within loyal but competing segments of Ottoman society. For those reformers from an earlier generation, still convinced of their vision of a loyal, militarily secure Ottoman Empire based on formally consolidated millets, they would have to struggle in opposition while a new generation of impassioned conservatives reacted to local contingencies in a new way. This tension over how to best react to the dramatic shift in fortunes as a result of the 1877-8 war was the crucial sociopolitical force at work for the last 40 years of Ottoman history (Karpat 2001).

\section{The Legacy of "Soft" Violence}

56 I have long argued that various manifestations of local agency-trade, politics, social, and cultural exchange-destabilizes the modern border-as-extension-of-state model of observing events. In place of the assumed geographic order the 1878 diplomatically drawn boundaries offered the region, peoples living within these reconstituted "borderlands" experienced the parallel trajectories of the still unharnessed modern world. In this regard, beyond laying out a detailed study of the new frontier administrations the new states of Montenegro and Serbia had to impose on their frontiers, I introduce cases of local mobilization that ultimately challenged these new borderland regimes and the sense of possibility for various political entrepreneurs directly affected by the Balkan Wars. In these cases, it was the contradictory demands of governance in reaction to local contingency, often introduced by investment schemes, that open up avenues of action for a number of indigenous actors and hence permit our rereading of the region's history at large, both prior to, and after, the Balkan Wars themselves.

That ascendant locals like Esad Pasha Toptani emerged in this period with considerable power only partially tells the story, however. Their activism did force ascendant regional state administrations to adapt to conditions they created on the ground, but as a result of a combination of factors, these adjustments created even more channels of engagement for locals. The consequences were a growing list of potential constituents, clients, and rivals to these ascendant locals and all the competing states created by the Treaty of Berlin in 1878-an Austro-Hungarian regime in Bosnia, Herzegovina, and Sancak, Serbia, Montenegro, Romania and an expended Greece. 

of local dynamics inducing, and reacting to, multiple external interventions, thus offers us an opportunity to explore the complexity of the modern world through largely ignored indigenous channels that are informed by the very Ottoman context in which they emerge. In a word, we are not simply dealing with nation-states and national heroes defined by boundaries. The transformations that contributed to the foundations of war in the Western Balkan towns remained a local experience that was then translated in other forms once filtered through the emerging state bureaucracies of the era.

What such a series of events suggests is that a local proved key to the initial process of accessing local natural resources. ${ }^{22}$ These developments could only happen with the collaboration of local leaders like Prenk bib Doda, who, thanks to the lobbying of Ottoman officials by the Austro-Hungarian diplomats in Vienna and Istanbul, was soon after freed from his exile. ${ }^{23}$ Interestingly, by the very fact Prenk bid Doda claimed authority (and thus ownership of these resources) the diplomacy that set him free put the burden of enforcement on the Catholic leader. This was crucial as locals, many deciding that Prenk bib Doda no longer represented their interests, resisted. The once primordial besa that supposedly tied an exiled "leader" to his people had broken, leading to any number of subsequent political reorderings of life in the larger Shkodër area. These changes were shaped on an alliance between commercial interests, the Ottoman state and rivals to Prenk bib Doda who were expected to use, and eagerly enforced, violent authority over the assumed subjects of once powerful "tribal" leaders who needed to be exiled. Such reorientation ultimately compelled key factions to reach beyond "traditional" spheres of association, including forming alliances with once rival/expansionist land owning families like the Toptanis. The long-term consequences of such an orientation of Shkodër political life will be discussed in later work; for now, the key point is these tropes functioned but not according to factors that take us beyond seeking the documented interactions between assumed local patriarchs and their state intermediaries.

As recently argued, the crucial link to begin to undermine the methodological shortcomings of past focus on such documented hierarchies is the aforementioned refugee populations that reoriented themselves, in large part, to serve as key extensions of various rival centers of power that undermined already constantly changing political alliances (Blumi 2013). Of those who opposed the expansion of predatory capitalism at the expense of their constituencies' wealth (and culture), refugees from the former Niš province and Herzegovina provided ample manpower to threaten violence. Similarly, Malësorë villagers were often mobilized to descend into town during market day, in full warrior attitude, to help express discomfort and frustration with certain decisions made by authorities and their erstwhile commercial partners. Indeed, these displays of formidable potential violence, coupled by the appearance of outspoken local-born priests, often impressed outsiders to believe, with the benefit of hindsight, that these could be the foundations of Albanian nationalist uprisings that destabilized the last of the Ottoman Balkans in 1910, and have since been glorified in Albanian nationalist historiography.

61 In this manner, revisiting the violent events in the region at the turn of the century contributes to the paradigm shift sought here. The cause for which well-armed mixed çeta groups fought the state and each other, which have long been mistakenly 
attributed to "ancient" ethnic and/or sectarian hatreds or a natural predilection to violence among backward Balkan peoples, can be more fruitfully explained by seeing events as a struggle to secure a safe home for family and fellow-community members. The events taking place in the late Ottoman Balkans were actually part of a productive exchange, no matter how contrived the nationalist tropes by a self-appointed intellectual vanguard rhetorically co-opting historical events in places like the larger Işkodra province may be. In fact, when the two contradictory states of social, economic, and political existence met (when, for example, Serbian state agents paid "Christian" peasants to fire guns at their Muslim neighbors) a sort of productive "friction" took place that ultimately constituted the historical force studied here. A more complicated analysis of what were the possible alternative agendas at play among some of the top personalities retroactively associated with nationalism in the western Balkans, in our case for the moment, Albanians like Esad Pasha Toptani, may help make the larger subversion of dominant paradigms in the historiography easier to accept.

\section{Conclusion}

There are, beyond the concerns with neighboring states' primordial/ideological interests in these regions, socio-economic explanations to consider. Moreover, these socio-economic rationales stem from an intimacy of direct, often collaborative exchange between constituencies that only in the war proved categorically antagonistic. For example, the appropriation of wealth by the victors, especially the property of many natives of the region, deserves our attention. Considering there are linking commercial interests involved in how property was taken from the previous inhabitants of western Balkan towns like Shkodër (and its suburbs) may help provide depth to the manner in which administrations, forced to deal with the threat of violence, approached potential instability in different ways after 1912. These evolving strategies of coercion and/or collaboration mobilized by officials who were often intimate with the constituencies they were expected to govern-as rivals or as partners -promises a complex set of layers to study late Ottoman/early post-Ottoman societies. Part of the task in respect to this is avoiding the presumption that violence in such settings is inevitable on account of primordial codes of behavior that limit how we can interpret honor. This skepticism extends to questioning how the threat of violence as a form of Ottoman and post-Ottoman state discourse was only ever addressed when geostrategic conditions in the larger Balkans changed.

63 Taking this interpretive range into consideration, this study identified different kinds of short and long-term social and political consequences of violence, as a conceptual possibility as much as an experience. Contrary to common belief, much of the problems associated with the increasing manifested violence in the region after 1878 actually stem from the idiosyncratic applications of "reforms" (and how historians have chosen to read them later) that seemingly undermined the capacity of various state administrations to manage their regional affairs effectively. These "reforms" correspond with a crucial outburst of what I call elsewhere "ethnic entrepreneurialism" that animates much of the Ottoman Balkans after 1878 in the form of the "nationalist revolt" retrospectively imposed by the scholarship (Blumi 2012: 110-116). The problem is these forms so communicable to a 21st century audience cannot so easily be assumed to mirror what are essentially post-Ottoman social and 
political orientations that still require a World War to take place. In other words, the implicit threat of violently disrupting social order in Ottoman (and nominally independent post-Ottoman states like Serbia, Greece and Montenegro) by way of mobilization along "ethnic" lines proved only valuable in certain contexts; other forms of threats of violence (with actual displays of violence recorded at times) also animated daily politics in the Ottoman Balkans that was mediated by oaths of honor or besa.

As suggested above, one possible approach to untangling the web of assumptions linking the prevailing stereotypes about how Balkan societies (at least in designated zones of backwardness) functioned with violence (or its potential) is to invest in studying the role natives of these societies objectified and perhaps exploited the stereotypes for their own careers. As needed intermediaries, the likes of Albanianorigin bureaucrats seem to have developed a particularly important reputation for "understanding" their objectified Albanian cousins. Placed in the context of lingering concerns in Istanbul about the very capacities of the reforming/transforming state to sustain direct rule in regions long assumed too primitive to fully embrace modernity on their own terms, regions like Malësi and its inhabitants long became the object of wild stories about the equivalent of the "wild west". Crucially, I suggest many of the late Ottoman perpetrators of this menace to Ottoman reforms were themselves selfidentified Albanians, whose insights into these societies would necessarily give their own authority greater weight, a kind of authenticity claim to local knowledge which linked primordial honor codes long associated with "besa" (a local term that eventually made it into the nomenclature of Ottoman and post-Ottoman state bureaucracies) to the greater cause of Modernity. ${ }^{24}$

\section{BIBLIOGRAPHY}

Anastasopoulos, Antonis (2007) 'Albanians in the Ottoman Balkans,' in Kolovos, Elias; Kotzageorgis, Phokion; Laiou, Sophia; Sariyannis, Marinos (eds.), The Ottoman Empire, the Balkans, the Greek Lands: Toward a Social and Economic History, Studies in Honor of John C. Alexander, Istanbul, Isis Press, pp. 37-47.

Avlonyalı Ekrem Bey (Dirim, Atilla, trans.) (2006) Osmanlı Arnavutluk'undan Anılar (1885-1912), Istanbul, İletişim.

Bilmez, Bülent (2003) ‘Sami Frashërior Šemseddin Sami? Mythologization of an Ottoman Intellectual in the Modern Turkish and Socialist Historiographies based on "Selective Perception" ', Balkanologies: revue d'études pluridisciplinaires 7 (2), pp. 19-46, URL: http:// balkanologie.revues.org/492.

Blumi, Isa (2011) Reinstating the Ottomans: Alternative Balkan Modernities, 1800-1912, New York, Palgrave McMillan.

Blumi, Isa (2012) Foundations of Modernity: Human Agency and the Imperial State, London, Routledge.

Blumi, Isa (2013) Ottoman Refugees, 1878-1939: Migration in a Post-Imperial World, London, Bloomsbury Academic. 
Boškovic, Aleksandar (2005) 'Distinguishing "self" and "other": Anthropology and National Identity in Former Yugoslavia', Anthropology Today 21 (2), pp. 8-13, URI: http://dx.doi.org/ 10.1111/j.0268-540X.2005.00339.x

Boyar, Ebru (2007) 'The Representation of the Balkans', in Boyar, Ebru, Ottomans, Turks and the Balkans: Empire Lost, Relations Altered, London, Tauris Academic Studies, pp. 42-71.

Burda, Ervis (2012) Customary Law and the Nation: The Significance of Kanun in the Emergence and Development of Albanian Nationalist Discourse, unpubl. PhD diss., SUNY Empire State College, URL: http://deepblue.lib.umich.edu/handle/2027.42/91824

Cushman, Thomas (2004) 'Anthropology and Genocide in the Balkans: An Analysis of Conceptual Practices of Power', Anthropological Theory 4 (1), pp. 5-28, URI: http://dx.doi.org/ $10.1177 / 1463499604040845$.

Dağlığlu, Hikmet Turhan (1934) şemsettin Sami Bey: Hayatı ve Eserleri, Istanbul, Resimli Ay Matbaasi.

Deringil, Selim (2003) “"They Live in a State of Nomadism and Savagery”: The Late Ottoman Empire and the Post-Colonial Debate', Comparative Studies in Society and History 45 (2), pp. 311-42, URL: http://www.jstor.org/stable/3879318.

Durham, Mary Edith (1909) High Albania, London, Edward Arnold, URL: http://archive.org/ details/afg4972.0001.001.umich.edu.

Durham, Mary Edith (1910) 'High Albania and its Customs in 1908', The Journal of the Royal Anthropological Institute of Great Britain and Ireland 40, pp. 453-72, URL: http://archive.org/details/ highalbaniaitscuoodurh.

Frashëri, Sami (1988) Vepra, 2 vols., Tirana, Instituti i Historisë.

Frashëri, Sami Bey (Ypi Kolonja, Abdyl, trans.) (1901) Besa: Drame me ghashte pamje, Sofia, Mbrothesia.

Galaty, Michael L. (2013) 'An Offense to Honor Is Never Forgiven...: Violence and Landscape Archeology in Highland Northern Albania', The Archaeology of Violence: Indeterdisciplinary Approaches 2, pp. 143-57.

Gawrych, George W. (2006) The Crescent and the Eagle: Ottoman Rule, Islam and the Albanians, 18741913, London, I.B. Tauris.

Herzfeld, Michael (1982) Ours once More: Folklore, Ideology, and the Making of Modern Greece, Austin: University of Texas Press.

Herzog, Christoph; Motika Raoul (2000) 'Orientalism "alla turca”: Late 19th / Early 20th Century Ottoman Voyages into the Muslim "Outback”, Die Welt des Islams 40 (2), pp. 139-95, URL: http:// www.jstor.org/stable/1570642.

İnalcık, Halil (1993) ‘Tanzimat'ın Uygulanması ve Sosyal Tepkiler', in İnalcık, Halil, Osmanlı İmparatorluğu: toplum ve ekonomi üzerinde arşiv çalışmaları, incelemeler, Istanbul, Eren Yayıncılık, pp. 361-424.

Kaleshi, Hasan (1964) 'Türkische Angaben über den Kanun des Leka Dukadjini', in Reichenkron, Günter; Schmaus, Alois (eds.) Die Kultur Südosteuropas: ihre Geschichte und ihre Ausdrucksformen, Vorträge, gehalten auf der Balkanologen-Tagung der Südosteuropa-Gesellschaft zu München vom 7.-10. Nov. 1962, Wiesbaden, Otto Harrassowitz, pp. 103-12.

Kaleşi, Hasan (1973) ‘şemsettin Sami Fraşeri’nin Siyasi Görüşleri,' in VII. Türk Tarih Kongresi, Ankara, Türk Tarih Kurumu, pp. 644-654. 
Karpat, Kemal H. (2001) The Politicization of Islam: Reconstructing Identity, State, Faith, and Community in the Late Ottoman State, Oxford, Oxford University Press.

Lord Byron (1812) 'Childe Harold's Pilgrimage', Canto the Second, Stanza LXV, URL: http:// knarf.english.upenn.edu/Byron/charold2.html.

Makdisi, Ussama (2002) ‘Ottoman Orientalism’, American Historical Review 107 (3), pp. 768-96.

Petrov, Milen V. (2006) Tanzimat for the Countryside: Midhat Pașa and the Vilayet of Danube, 1864-1868, unpubl. Ph.D. Dissertation, Princeton University, Princeton.

Pula, Besnik (2013) 'Binding Institutions: Peasants and Nation-State Rule in the Albanian Highlands, 1919-1939', Political Power and Social Theory 25, pp. 37-70, URI: http://dx.doi.org/ 10.1108/S0198-8719(2013)0000025008.

Reinkowski, Maurus (2003) 'Double Struggle, No Income: Ottoman Borderlands in Northern Albania', International Journal of Turkish Studies 9, pp. 239-53, URL: http://www.freidok.unifreiburg.de/volltexte/3156/pdf/Reinkowski_Double_struggle.pdf.

Reinkowski, Maurus (2005a) 'Aḥmed Cevdet Efendis Mission nach Shkodër', in Reinkowski, Maurus, Die Dinge der Ordnung: eine vergleichende Untersuchung über die osmanische Reformpolitik im 19. Jahrhundert, Munich, R. Oldenbourg Verlag, pp. 189-94.

Reinkowski, Maurus (2005b) 'Zusammenfassende Diskussion', in Reinkowski, Maurus, Die Dinge der Ordnung: eine vergleichende Untersuchung über die osmanische Reformpolitik im 19. Jahrhundert, Munich, R. Oldenbourg Verlag, pp. 264-78.

Rira, Miranda (2012) 'Anomie and Honor in the Albanian Society', Mediterranean Journal of Social Sciences 3 (3), pp. 203-210. URI: http://www.mcser.org/images/stories/2_journal/ mjss_september_2012/miranda\%20rira.pdf.

Saraçoğlu, M. Safa (2008) 'Some Aspects of Ottoman Governmentality at the Local Level: The Juicio-Administrative Sphere of the Vidin County in the 1860s and 1870s', Ab Imperio 8 (2), pp. 223-54.

Sommers, Tamler (2009) 'The Two Faces of Revenge: Moral Responsibility and the Culture of Honor,' Biology \& Philosophy 24 (1), pp. 35-50, URI: http://dx.doi.org/10.1007/s10539-008-9112-3. şemseddin Sami (1875) Besa Yahud Ahde Vefa: Altı Fasıldan Ibaret Facia, Istanbul, Tasvir-i Efkar Matbaasi.

Şemseddin Sami, (1996) Kamus al-A'lam: Tarih ve Coğrafya Lugati ve Tabir-i Esahhiyle Kaffe-yi Esma-yı Hassayı Camiidir, 6 vols., Istanbul, Mihran Matbaası, 1306 [1889]; repr. Ankara, Kaşgar Neşriyat.

White, Hayden (1972) 'The Forms of Wildness: Archaeology of an Idea', in Dudley, Edward; Novak, Maximillian E. (eds.) The Wild Man within an Image in Western Thought from the Renaissance to Romanticism, Pittsburgh, University of Pittsburgh Press, pp. 150-182, URL: http://abuss.narod.ru/ Biblio/eng/white_tropics.pdf.

\section{NOTES}

1. "Imperial" interests in the Balkans include Italy's delicate balancing of its immediate strategic interests and long-term concerns with expanding Greek, Serbian/Russian, and Austro-Hungarian influence. In this context, massaging relations with locals to suit one external set of interests at the expense of others may require considerable "local knowledge" that at once exploits domestic honor codes and assures indigenous sensibilities are not insulted. 
2. I am ready to concede that this deeper elaboration of causes and consequences in a geographically limited arena only further muddies the waters. At the same time, however, I must stress the importance of not seeking to encapsulate in any single narrative the dynamics contributing to and ultimately transforming the lives of those involved, even in such a narrow scope as covered here. Therefore, I am offering a corrective in the sense that it offers other possible ways to asking questions of our sources, in effect highlighting events transpiring prior to, during and after the wars as stimulants for new social, political, economic, and/or cultural orientations.

3. The selective use of "tradition" has long been a favorite method of national mythmaking in the Balkans, with well-established projects of defining Greek identity through "folklore" studies the useful example to which we can point as I proceed to analyze critically equivalent uses in Albanian sources (Herzfeld 1982).

4. The most famous agent of empire who traveled and "studied" the inhabitants was Edith Durham (1910).

5. Most often, the act of violence is imposed with a variant that the participants were "honorbound" thus excluding analytical alternatives as possible explanations. According to scholars inclined to find universal causality in ethno-cultural patterns among pre-modern peoples, in Northern Albania, custom and duty account for the violence (Sommers 2009).

6. A nuance highlighted in (Reinkowski 2003: 248).

7. Therefore, simply referring to "Albanians" in a wider Ottoman context may be missing the regional distinctions that many prominent Ottoman officials, again, many of whom were of Albanian origin, used to differentiate just who was targeted for reform. Many who write on "Ottoman" attitudes toward "Albanians" miss this nuance (Anastasopoulos 2007).

8. An essentialism that was not exclusively European (Deringil 2003; Herzog, Motika 2000).

9. Başbakanlık Arşivi (BBA), Irade Dahiliye 23192, Message to newly appointed administrator of Shkodër, Mustafa Pasha, dated 1856, p. 1.

10. Also known as Wassa Effendi and/or Vaso Pasha in the documentation.

11. Military expeditions were often a product of such strategies, leaving stubbornly autonomous people of Malësi constantly facing state violence advocated by southern Tosk officials. For details of one such campaign that originated in Dibër in the height of the winter, see Haus, Hauf und Staatsarchiv (HHStA), PA, XXXVIII, 201, Wassitch to Andrassy, dated Scutari, Dec. 23, 1873.

12. Even well into the Abdülhamid period, authorities debated the best approach to changing the region. In one report, demands were made for additional judges and police officers and for schools to be set up in Malësi as the region suffered from many of the same ills mentioned by the reforms in the 1860s: BBA, Yıldız Sadaret Resmî Maruzat Evrakı (YA.RES), 71/35, No. 339, Yıldız Sarayı to Meclis-i Vükela, dated 5 Safer 1312 (Aug. 9, 1894).

13. Revealingly, Turkish nationalists today spend considerable time making the claim that Sami's loyalties lay with a modern Turkish identity, framed in Ottoman terms, in direct contrast to claims that Sami was unequivocally an Albanian nationalist (Bilmez 2003). I argue that Sami was a loyal Ottoman subject who not only advocated the development of regional vernaculars such as Toskërisht but also emphasized the need for Ottoman to be the language of an empire that was the cultural melting pot of the eastern Mediterranean and Central Asian world.

14. In letters written in Toskërisht to activists in Italy and elsewhere, Sami notes a tension between what some beyond the Ottoman Empire hoped was the beginning of a drive for political separation and a still strong sense of affiliation among prominent Ottoman-Arnavut/Shqiptar, figures such as Sami. See Albanian National Archives (AQSH), F.51.D.4.f.1-3, Sami Frashëri to Jeronim de Rada, dated Istanbul, Feb. 20, 1881.

15. Sami was unambiguous in identifying Albanians (Arnavutlar) of all faiths, as well as Muslim Slavs, as integral parts of the great Islamic nation and as members of the Ottoman state. This is 
an emphasis on social cohesion in the larger empire on Islamic terms that are rarely pointed out today (Frashëri 1988, 1: 21).

16. Sami Frashëri was a careful scholar and his meticulously written encyclopedia provides insight into a world he had no problem segregating into regions-Gegallk and Toskalı-and even more narrowly into villages that he and his fellow Ottoman subjects felt had shaped their own personal hybrid identity. Sami, for one, asserts that his hometown was a bastion of civilization set in a larger Balkan/Albanian context of ignorance. See his entry for his hometown (şemseddin Sami 1996, 5: 3353).

17. The working trope infused much of the popular literature-and resulting "scholarship"-in the Habsburg Empire, a crucial player in shaping inter-communal relations for the years leading to World War I. The Ottoman state learned of stories in Vienna newspapers about the particularities of Albanian honor codes, that they were a source of disloyalty to the Sultan, a wedge many in Vienna's power circles hoped to exploit. BBA, Bab-1 Ali Evrak Odas1 340/25431, report from Ministry of War, dated 1 B 1311.

18. The play was translated and printed in Sofia by activist A. Ypi Kolonja in (Frashëri 1901).

19. There are a number of reasons why scholars have misinterpreted the play as representing a glorification of highland values. That being said, reading it in the most literal sense (and after all, it was meant to be performed on stage) suggests that this tragedy was meant to convey a clearcut message very much in line with the Ottoman reform movement's goals (Gawrych 2006: 15-18). 20. Some noted the state attempts to reduce the number of vendettas between communities in and around Prizren, Prishtina, and Peja (Ipek), a direct consequence of local struggles for power (Durham 1909: 112).

21. In response to the Russian military victories and recognizing that there would be serious territorial consequences, a number of organizations were formed in the later months of 1877 to lobby European powers for the return of the status quo (i.e., no territorial rewards to the Russian state). One of these organizations was the Central Committee for the Defense of the Rights of the Albanian People, founded by Istanbul-based regional intellectuals in December 1877 in Istanbul. Contrary to what most scholars read into the committee, it seems clear that its initial purpose was to protect Ottoman interests by soliciting the European public (such organizations would send open letters to newspapers), claiming that they were part of national communities operating independently from the Ottoman state (Gawrych 2006: 43-45).

22. By 1910, Bid Doda Pasha was on a "first-name" basis with Italian foreign ministry officials and a collection of his letters discussing his haggling between Italian and Austrian companies suggests he was clearly in control of his region's resources, Archivio Storico del Ministero degli Affari Esteri (ASMAE), Ambass 220, no. 4848, Bid Doda Pasha to Llima, 3 Nov. 1910.

23. Suggestively, Prenk bib Doda Pasha's career as both a local power holder and a future partner in the timber industry starts even earlier. Evidence found in reports coming out of Lebanon in the 1870s suggest the Austrian representatives, along with the Ministry of Mines and Forests, and prominent local Arab leaders linked to the Malhame family, were actively promoting Prenk Bib Doda for a possible appointment as the top administrator for Mount Lebanon. BBA, YA.RES 20/19, dated Vienna, 16 C 1300 [24 Apr. 1883]. Prenk Bid Doda would soon be the centre of much debate over his role as appointed Mutassarif of Lebanon to replace the deceased Vasa Paşa [Pashko Vasa], another Mirdita Catholic who set off the successful reforms of the province.

24. Indeed, family feuds based on older conflicts back in the Balkans continued to plague refugee communities in Anatolia as they were forced to resettle after the collapse of the empire's Balkan provinces in 1912-1913. 


\section{ABSTRACTS}

This is a study of the shifting fortunes of Ottoman western Balkan regions (represented here in their main towns) at the end of imperial rule. It reads the evidence of certain internal dynamics to reconsider what are the animating forces at work during a period of state reorientation such as that of 1878 to 1918. Using the cases of the Ottoman western Balkans as extensions of broader regional interactions between (not so neatly distinctive) state and subject actors, it becomes clear that the origins of certain kinds of social upheaval are linked to local socio-economic forces directly affiliated with administrative reforms. What is often missing in early readings of these reforms is that many were adopted to harness local practices of conflict resolution. As argued throughout, the local forces engaging with presumably distinct state actors would ultimately influence new regional conditions that were often registered as indigenous principles or "values". The manner in which state authorities tried to co-opt these local practices often proved violent. Such violence invariably appears in the documents. Where this paper seeks to go, however, is to highlight how the violence alone cannot serve as our focus to better understand how change is brought to the region. Rather, it aims to show how indigenous forms of mediating violence, often through honor codes, as in the Albanian case studied here, known as besa, we can begin to better understand the complicated intersections of institutional changes and indigenous actors.

\section{INDEX}

Keywords: Albania, violence, honor, Ottomans, folklore

\section{AUTHOR}

\section{ISA BLUMI}

Associate Professor, Georgetown University 